\title{
A Case of Septal Abscess Extending to the Nasal Dorsum
}

\author{
Hye-Ran Son, Ji-Hun Mo and Young-Jun Chung \\ Department of Otorhinolaryngology-Head \& Neck Surgery, Dankook University College of Medicine, Cheonan, Korea
}

\section{비배부로 확장된 비중격 농양}

손혜란 · 모지훈 · 정영준

단국대학교 의과대학 이비인후-두경부외과학교실

\author{
Received January 16, 2013 \\ Revised July 4, 2013 \\ Accepted July 4, 2013 \\ Address for correspondence \\ Young-Jun Chung, MD \\ Department of Otorhinolaryngology- \\ Head \& Neck Surgery, \\ Dankook University \\ College of Medicine, \\ 201 Manghyang-ro, Dongnam-gu, \\ Cheonan 330-715, Korea \\ Tel $+82-41-550-3974$ \\ Fax $+82-41-556-1090$ \\ E-mail entdocjung@hanmail.net
}

Nasal septal abscess is an uncommon entity and causes nasal obstruction, saddle nose deformity and septal perforation. It is defined as a collection of pus between the cartilage or bony septum and its normally applied mucoperichondrium or mucoperiostium. Previously reported cases are confined in the nasal septal space and case of nasal septal abscess extending to nasal dorsum has not yet been reported in the literature. We recently experienced an extremely rare case of nasal septal abscess which extended to the nasal dorsum and caused abscess on the nasal dorsum. Therefore, we present this case with a brief review of literature.

Korean J Otorhinolaryngol-Head Neck Surg 2014;57:116-9

Key Words Abscess · Nasal dorsum · Nasal septum.

\section{서 론}

비중격 농양은 비중격 연골부와 연골막 사이, 비중격 골부 와 골막 사이에 농양이 고이는 질환으로 비교적 드물게 발생 한다.1) 염증이 진행될수록 고인 농양이 연골과 연골막을 분리 시켜 연골에 공급되는 혈류를 차단함으로써, 농양에 의한 압 력과 허혈성 변화에 의해 비중격 연골은 24 48시간 이내에 괴사하게 된다. ${ }^{2)}$ 비중격 농양 발생시 코막힘, 전두통, 비배부 동통과 압통, 전신 쇠약감, 비루 등의 증상이 발생하며, 염증 이 진행하는 경우에는 안장코, 뇌막염, 패혈증 등의 합병증이 발생하기도 한다. ${ }^{13)}$ 대부분이 외상성 원인에 의해 발생하지만, 드물게 비전정염, 급성 부비동염, 치성 감염 등의 염증성 원인 이나 환자의 면역능 저하 등이 원인이 되어 발병되기도 한다.13)

현재까지 문헌에 보고된 비중격 농양 증례들은 모두 비중 격에 국한되어 발생한 것으로, 비배부까지 침범하여 농양이 형 성된 증례는 아직까지 보고된 바가 없다. 최근 저자들은 비배 부까지 침범해 농양을 형성한 비중격 농양 증례를 경험하였 기에, 이를 문헌 고찰과 함께 보고하고자 한다.

\section{증 례}

38세 남자 환자가 일주일 전부터 시작된 비폐색과 발적을 동 반한 비배부의 종창을 주소로 내원하였다. 환자는 개인의원 에서 부비동염으로 진단을 받고 일주일간 항생제를 처방 받아 복용하였으나, 비강 내 팽창감과 비강 내 통증이 심해지고 2 일 전부터 비배부 종창이 발생하여 본원을 방문하였다. 어렸 을 적 코를 다친 후 외비 변형이 초래된 과거력이 있었으며, 치 과 시술력이나 다른 특이 질환의 과거력은 없었다.

내원시 시행한 비내시경 검사에서 양측 비강을 가득 채운 비중격 종창 소견이 관찰되었고(Fig. 1), 비배부에 발적을 동 반한 종창 소견이 관찰되었다(Fig. 2). 비인두 부위에서 후비 루 소견은 없었고, 전신적인 발열, 오한은 내원 당시에는 호소 하지 않았다. 내원 당일 시행한 혈액 검사에서 백혈구 수치는 $9580 \mathrm{~mm}^{3}$ (호중구 60.9\%), C 반응성 단백(C-reactive protein, CRP) $3.63 \mathrm{mg} / \mathrm{dL}$ 였고, 그 외 특이소견은 없었다. 부비동 전 산화단층촬영에서는 비중격 미부에 저음영 병변(low density lesion)이 관찰되었고, 이 음영은 비배부(nasal dorsum)까지 
연결된 소견이었다(Fig. 3).

내원 당일 국소 마취하에 절개 배농술을 시행하였다. 좌측 비중격 미부에 반관통 절개를 시행하여 농성 분비물을 배농 한 후, 농성 분비물에 대한 세균 배양 및 그람 염색을 시행하 였다. 배농 후 비중격을 관찰하였을 때 비중격 연골은 대부분 괴사된 양상이었다. 비배부의 농양은 주사기를 이용해 흡인 을 시도하였지만, 흡인되지 않았다. 수술 중 비배부에 압박을
가하여 비중격 내부로 배농이 되는 것을 확인하고, 비배부에 반복적인 압박을 시행하여 비배부의 농양을 배농하였다. 이후 생리식염수로 비중격 내부를 반복적으로 세척한 후, 배액관 삽입 없이 고정봉합(quilting suture)을 시행하였다. 그리고 항 생제 연고를 묻힌 거즈로 양측 비강을 충전하고, 비배부에 압 박 드레싱을 시행한 후 수술을 종료하였다. 술 후 항생제(ceftriaxone $2 \mathrm{~g}$ once daily, clindamycin $600 \mathrm{mg}$ three times dai-

Fig. 1. Preoperative endoscopic findings. Both nasal cavities are filled up with bulging septum. Right nasal cavity (A). Left nasal cavity (B).
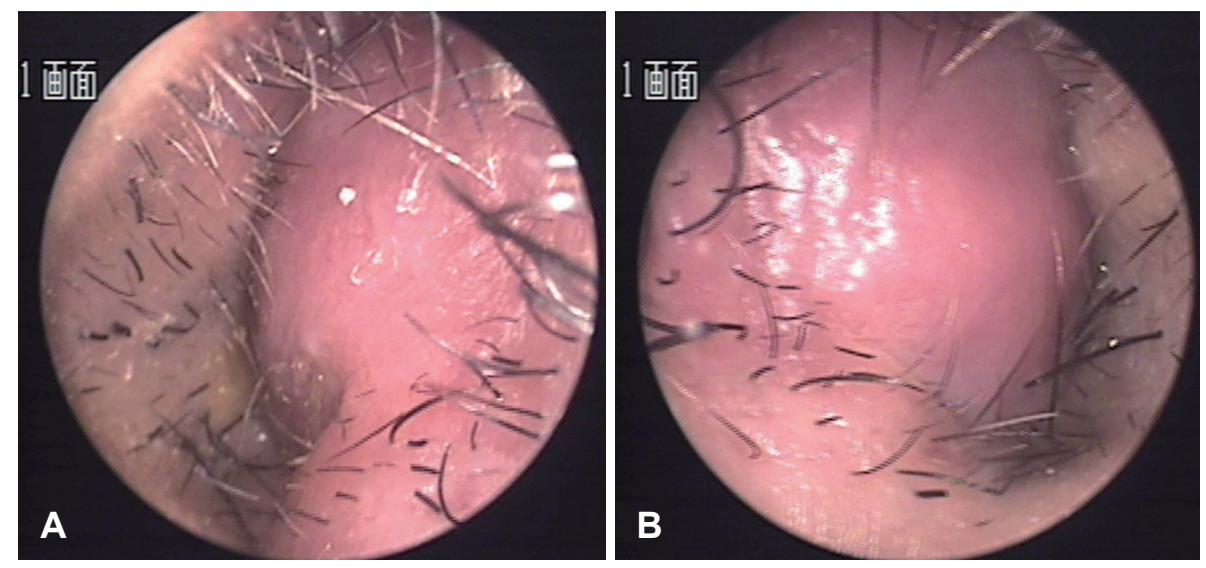

Fig. 2. Photograph of face. Nasal dorsum was erythematous and markedly swollen. Frontal view (A). Lateral view (B).
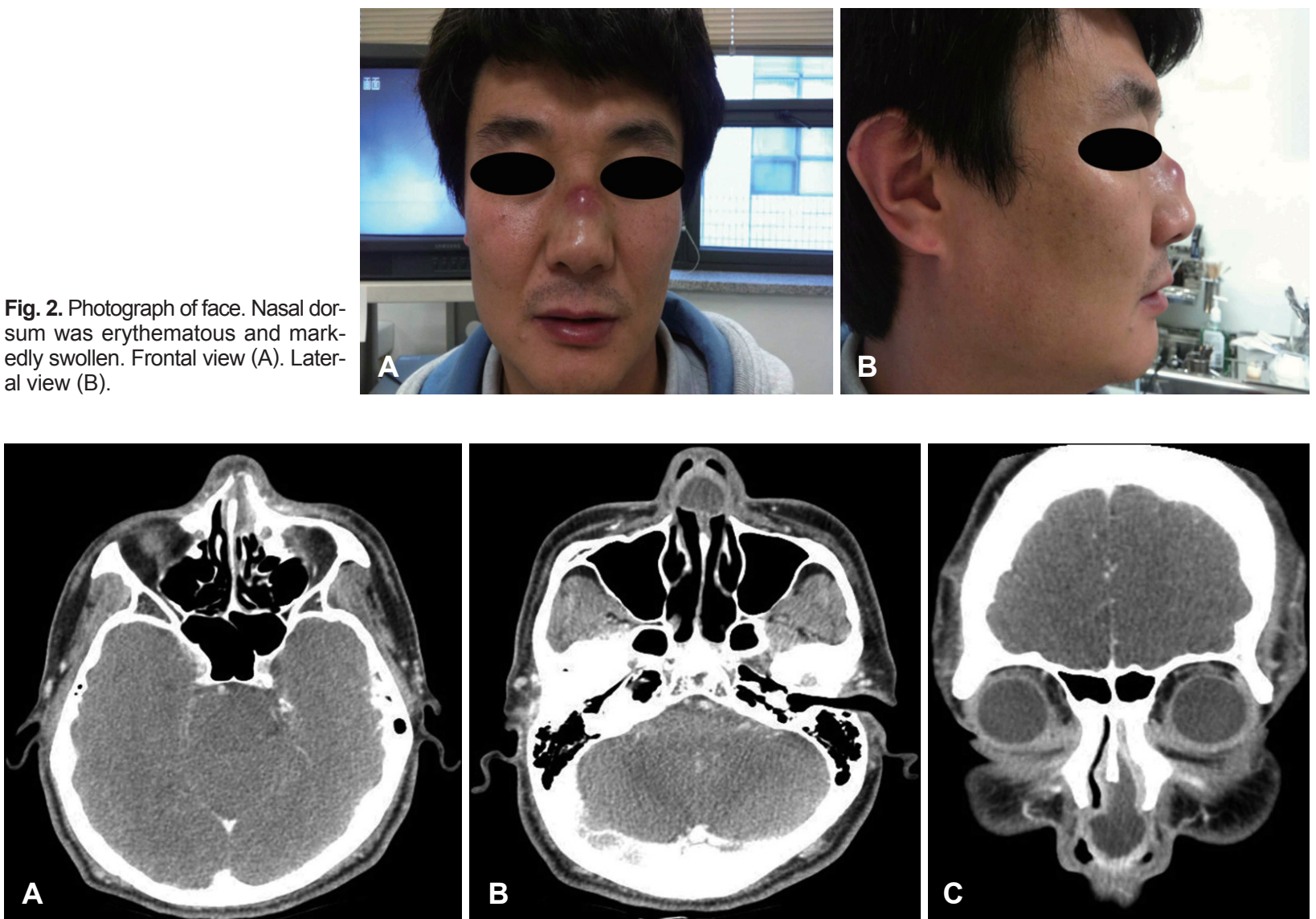

Fig. 3. Axial CT scans (A and B) and coronal CT scan (C) demonstrate that nasal septal abscess extended to the nasal dorsum and caused abscess on the nasal dorsum. 
ly)를 정맥으로 투여하였고, 술 후 2일째 비강 내 충전물을 제거 한 후 퇴원하였다. 수술시 시행한 균 배양 검사에서는 Staphylococcus aureus 가 동정되어, 연골성 병변을 고려하여 감수 성 있는 항생제 중 gemifloxacin $320 \mathrm{mg}$ 을 추가적으로 1주 간 복용하였다.

퇴원 후 외래에서 재발 및 안장코 발생을 확인하기 위해 주 기적으로 추적 관찰을 계획하였다. 술 후 3개월째 안장코가 발생하여 외비성형술을 권유하였으나, 이후 자의적으로 외래 경과 관찰을 중단하였다. 술 후 1년된 시점에 외래를 다시 방 문하였는데, 술 후 6 개월째 개인 병원에서 필러 시술을 받은 후 비배부의 안장코 변형이 다시 초래된 상태였다. 비중격 및 비배부의 농양은 재발 소견이 보이지 않았고, 환자 개인 일정 을 고려하여 외비성형술을 계획하고 있다.

\section{고 찰}

신체 검진에서 비중격 연골부에 국소적인 종창과 파동이 관 찰되면, 비중격 농양을 의심하고 즉각적인 절개 배농술을 시 행해야 한다. 적절한 시기에 치료되지 않는 경우에는 드물게 해면정맥동 혈전증, 뇌막염, 패혈증 등의 합병증으로 진행되 어 사망하는 증례도 보고되었으며, ${ }^{1,3,4)}$ 비중격 연골의 괴사로 인하여 비중격 연골에 의해 지지되는 연골성 비배부에 안장코 가 발생할 수 있다.

Keystone 영역은 비골, 연골성 비중격, 골성 비중격, 그리고 상외측연골이 연골막과 골막의 단단한 섬유성 연결로 서로 결 합되어 있는 부위로 한국인의 경우 정중선에서 평균 $7.6 \mathrm{~mm}$, 정중곁선(paramedian) 부위에서는 평균 $2.6 \mathrm{~mm}$ 가 겹쳐 있 다.) 따라서, 이런 keystone 영역의 해부학적 특징 때문에, 일 반적으로 비중격 농양이 발생하더라도 주변 구조물로의 침범 없이 비중격에 국한되어 발생한다.

이런 keystone 영역은 한국인에서 다양한 정도의 폭과 길이 로 맞물리기 때문에, 상외측연골 및 비골의 중첩된 모양과 비 골 미부의 형태가 개인에 따라 다양하게 관찰된다. 비골 미부 와 상외측연골의 중첩이 충분하여 강한 결합의 형태를 보이 는 경우도 있지만, 상외측연골과 비골의 중첩된 모양이 Type A (flat margin)이면서 비골 미부 모양이 Type D(retracted midline)인 경우에는 중첩 면적이 작아 가장 약한 형태의 연결을 보이는 경우도 존재하고, 정중곁선 부위에 중첩이 없이 비골과 상외측연골이 느슨하게 결합되어 있는 형태도 존재한다. ${ }^{5}$

본 증례처럼 비중격 농양이 비배부로 확장된 경우에 다음과 같은 발생 기전을 생각해 볼 수 있다. 첫째, 환자의 비골과 상 외측연골 사이 결합이 약한 형태를 가진 경우라면 비중격 농 양이 느슨하게 결합된 keystone 영역을 따라 비배부로 확장
되었을 가능성을 생각해 볼 수 있다. 둘째, 외상으로 초래된 외비 변형의 과거력이 있기 때문에, 외상 당시 전사골동맥의 외비 분지가 경미한 손상을 입었을 가능성이 있다. 전사골동 맥의 외비 분지는 keystone 영역을 통과해 외비에 혈액을 공 급하는 분지로, 이 동맥의 경미한 손상으로 발생한 혈종으로 keystone 영역의 섬유성 결합이 느슨해져 비중격 농양이 비배 부로 확장되는 데 교통로를 제공했을 가능성도 추측해 볼 수 있다. 마지막으로, 수술 전 시행한 전산화단층촬영에서 비골 골절선이 관찰되고 이 부위를 통해 비중격 농양과 비배부 농 양이 연결된 양상이기 때문에, 과거 외상으로 발생한 골절선 을 통해 농양이 비배부로 확장되었을 가능성도 있을 것으로 판단된다.

본 증례와 감별해야 할 질환으로 감염된 정중선 종물의 가능성을 고려해야 하며 비배부에 발생할 수 있는 정중선 종 물로는 유피낭종, 뇌류, 교종이 있다. 뇌류와 교종은 대부분 주로 어릴 때 비배부의 커지는 종물이나 두개 내 합병증이 발생되어 발견되는 드문 질환으로 본 증례에서처럼 성인에서 감염이 되어 발견될 가능성이 매우 낮다. 또한 이는 영상학적 검사를 시행하였을 때 중추신경계의 연결을 보이나 본 증례 환자의 전산화단층촬영상 중추신경계와의 연결이 관찰되지 않으므로 배제해 볼 수 있다. 반면 유피낭종은 선천성 질환 으로 대부분 3세 이전에 진단되며 아주 드물게 성인이 되어 진 단되는 경우도 있다.) 크게 두 가지로 나누어 비배부에만 국한 된 경우를 단순형(simple), 이 외의 경우를 복합형(complex)으 로 분류한다. 복합형인 경우에는 유피낭종이 비골을 딿고 비 중격, 뇌기저부, 두개 내까지 침범할 수 있다. ${ }^{7)}$ 조직 검사를 통해 진단 후 완전 절제해야 하며 절개 배농이나 조대술, 경화 술 등의 부적절한 치료를 시행하면 쉽게 재발하는 것으로 알 려져 있다. ${ }^{8)}$ Vaghela와 Bradley ${ }^{2)}$ 는 성인에서 나타난 유피낭종 44 명의 증례를 분석하였는데, 이 중 $89 \%$ 는 비종물의 형태로 발견되어 진단되었고, $11 \%$ 는 두개 내 합병증의 발생으로 진단 되었다. 비종물로 진단된 89\%의 환자 중 $73 \%$ 는 비배부, $9 \%$ 는 비첨부, $7 \%$ 는 미간에서 발생했다고 보고하였다.

지금까지 보고된 문헌에서 성인에서 발견된 유피낭종 중 비 중격에서 발생하였다는 보고는 없으며, 이는 비중격에서 유피 낭종이 발생한다면 비폐색 증상으로 어린 나이에 진단될 것으 로 생각된다. 따라서 유피낭종의 가능성을 생각한다면 비배부 에서 발생하였을 가능성이 크다. 위에서 언급했듯이 본 증례 의 환자는 전산화단층촬영에서 과거 외상력으로 인해 비골 골절선이 관찰되며 비중격 농양과 비배부 농양이 연결된 양 상을 보이기 때문에 유피낭종이 비골을 침범하여 비중격 농양 까지 진행될 수 있지만, 환자의 증상이 비중격 종창에 의한 비 폐색이 우선적으로 발생한 이후 비배부 농양이 발생하였기 때 
문에 감염성 유피낭종의 가능성은 떨어진다. 두 번째, 유피낭 종은 외배엽과 중배엽 기원으로 낭종 내에 각화물질이나 콜 레스테린 결정, 피부부속기관 등이 포함되어 있다. 하지만 본 증례의 환자에서는 수술시 농양을 제외한 다른 내용물은 관 찰되지 않았다. 마지막으로 수술시 비배부의 병변에 대해서 는 비중격 피판만 거상한 후 비배부를 압박하여 비중격 내부 로 배농술만 시행하였기 때문에, 만일 유피낭종이었다면 재 발 가능성이 매우 높지만, 1 년이 지난 시점까지 재발 소견이 없 다는 점으로 유피낭종의 가능성은 낮다고 판단된다. 수술시 중심성 낭종의 감염성 병변을 시사할 만한 특이 소견이 관찰 되지 않아 배농술만 시행하고 조직학적 검사를 시행하지 않 은 점이 본 증례가 가진 한계점으로 생각된다.

본 증례는 비중격 농양이 비중격에만 국한되지 않고, 비배 부로 확장되어 발생한 첫 증례 보고이다. 이전 외상의 과거력 이 있는 경우나 keystone 영역의 결합이 약한 경우에는 드물 게 비중격 농양이 비배부까지 확장되어 임상적으로 발현될 수 있음을 보여주는 증례로, 비배부의 종창이 있는 경우에는
비중격 농양의 동반 여부 및 정중선 종물 등 다른 질환과의 감별이 반드시 필요할 것으로 판단된다.

\section{REFERENCES}

1) Ambrus PS, Eavey RD, Baker AS, Wilson WR, Kelly JH. Management of nasal septal abscess. Laryngoscope 1981;91(4):575-82.

2) Vaghela HM, Bradley PJ. Nasal dermoid sinus cysts in adults. J Laryngol Otol 2004;118(12):955-62.

3) Walker R, Gardner L, Sindwani R. Fungal nasal septal abscess in the immunocompromised patient. Otolaryngol Head Neck Surg 2007; 136(3):506-7.

4) Collins MP. Abscess of the nasal septum complicating isolated acute sphenoiditis. J Laryngol Otol 1985;99(7):715-9.

5) Kim IS, Chung YJ, Lee YI. An anatomic study on the overlap patterns of structural components in the keystone area in noses of Koreans. Clin Exp Otorhinolaryngol 2008;1(3):158-60.

6) Bilkay U, Gundogan H, Ozek C, Tokat C, Gurler T, Songur E, et al. Nasal dermoid sinus cysts and the role of open rhinoplasty. Ann Plast Surg 2001;47(1):8-14.

7) Bradley PJ. The complex nasal dermoid. Head Neck Surg 1983;5(6): 469-73.

8) Nydell CC Jr, Masson JK. Dermoid cysts of the nose: a review of 39 cases. Ann Surg 1959;150:1007-16. 